\title{
WINTER RECEPTION AND TRANSIT CENTER IN THE REPUBLIC OF CROATIA: AN ETHNOGRAPHIC VIEW OF THE SLAVONSKI BROD REFUGEE CAMP ${ }^{1}$
}

Original scientific paper Received: 16. 11. 2016 Accepted: 25. 11. 2016 DOI: $10.15176 / \mathrm{vol} 54 \mathrm{no} 106$

UDK $323.28-054.73$ 341.43 $364-56(497.542$ Slavonski Brod)"2016"

\author{
MARIJANA HAMERŠAK \\ Institute of Ethnology and Folklore Research, Zagreb \\ IVA PLEŠE \\ Institute of Ethnology and Folklore Research, Zagreb
}

\begin{abstract}
Starting in January and ending in April 2016, we stayed at the Winter Reception and Transit Center - i.e. the refugee camp in Slavonski Brod - on a number of occasions. At this time, this was the only place where refugees from the war-stricken, or otherwise deprived countries could stop on their way to Western Europe. This paper deals with the methodological issues, research methods and procedures (ranging from entering the field and the issues of researcher and participant roles, through observation and note taking to participation, and interviews) which we were employing and testing during our stay at the camp, and which we consider significant for the understanding of the camp itself. We focus on the numerous faces of methodological reductionism and methodological pluralism of our research at the camp. Certain ethnographic methods in our study were frequently reduced to their bare contours, but, upon taking a step away or their combination with other methods, they opened and created multiple doorways to the research field, taking on, among other things, the characteristics of investigative work.
\end{abstract}

Keywords: methodology, ethnography, refugees, refugee camp, participant observation, fieldnote, interview

In September 2015, the European long summer of migration metaphorically crossed into the long migration autumn. This is the time when Hungary closed its borders with

${ }^{1}$ This article is to appear in the edited volume entitled Kamp, šator, granica: studije izbjeglištva u suvremenom hrvatskom kontekstu (Camp, Tent, Border: Studies of Refugeehood in the Contemporary Croatian Context) (Institute of Ethnology and Folklore Research, 2017), and is published here with the permission of the volume editors. 
Serbia for refugees, redirecting the transcontinental refuge of men, women and children (from Syria, Afghanistan, Iraq, Pakistan and other countries stricken by wars and conflicts, restrictions, suffering and devastation) from Serbia through Croatia. ${ }^{2}$ After the initial period, when the journey of smaller or larger groups of people through Croatia towards Western Europe was partially organized by state services and partially individual (in part with the help of Croatian citizens), the first Croatian refugee transit center was opened in Opatovac, making it yet another European station for assembling, classifying and directing people (cf. e.g. De Genova et al. 2016). November 3, 2015 marks the opening of the Winter Reception and Transit Center, i.e. the Slavonski Brod refugee camp, which became the central spot of the Croatian section of the Balkan corridor, which had been essentially established in the meantime. The corridor can be described as a mobile form of contemporary humanitarian-securitarian migration management regime, based on territorial and administrative externalization and internalization of border controls, and declaratively depoliticized policies of humanitarian protection (cf. e.g. Cobarrubias et al. 2015; Kasparek 2016; Scheel et al. 2015). ${ }^{3}$

Starting with the very first days and weeks of that autumn we were handing out clothes, sandwiches, or sometimes simply being there at the various refugee transit points, among other things, constantly asking ourselves how our disciplines could help in understanding the event that we were witnessing: an exodus transforming the concepts of geographical distance, human strength, compassion, solidarity, coercion and cruelty, wars, their causes, consequences and victims before our very eyes. Long-term, field-based research emerged as a way to try to join in through our disciplines. As a result, in January of 2016, alongside our colleagues from the Institute of Ethnology and Folklore Research (Zagreb), we came to the Slavonski Brod camp as researchers for the first time. At the time, this was the only place in Croatia designed to be a stopover for refugees, which made it the only potential research space where the Croatian section of the corridor could be studied. ${ }^{4}$ We

${ }^{2}$ The countries of origin are mentioned on the basis of data presented in the International Organization for Migration annual report for 2015: http://doe.iom.int/docs/Flows\%20Compilation\%202015\%200verview.pdf. These and other statistical data are generally empirical and ideologically debatable on multiple grounds (cf. e.g. Stierl et al. 2016), and we mention them here without pretensions of representativeness or precision, so as to provide some basic parameters on the topic.

${ }^{3}$ A retrospective insight into different daily dynamics of migrations that are dealt with in this text can be obtained through notifications regularly published by the Ministry of the Interior on its website from 16 September 2015 until the end of January 2016 in the category notifications about the reception and accommodation of migrants in the Republic of Croatia, from daily reports that Inicijativa Dobrodošli! ("Welcome" Refugee Support Initiative) published online from 26 September 2015, and through daily reports of the organization Are you Syrious? (AYS Daily News Digest) that have been regularly published online since September 2015. Other reports from a variety of sources, differing in levels of reliability, scopes and interests may also serve as a way to reconstruct the dynamics of the corridor, as well as connections between the political context, decisions, actions taken and others issues, cf. e.g. Banich et al. (2016a and 2016b); Documenta [2015]; Hrvatski Crveni križ (2016); Inicijativa Dobrodošli (2016); Martinović Džamonja et al. (2016); Mouzourakis and Taylor (2016); Moving Europe (2016); Sigurnosno-obavještajna agencija (2016); Šelo Šabić and Borić (2016); Ured pučke pravobraniteljice (2016).

${ }^{4}$ According to the data made publically available by the Ministry of the Interior, a total of 374,148 persons arrived in the camp, which is an approximate number. Several hundred to several thousand people 
kept coming back to the camp until the spring, and the last time we were there was immediately before 12 April 2016, when the last group of refugees was taken from the camp.

Our ethnographic research in the camp proved to be fraught with methodological dilemmas, problems and obstacles, which we were able to anticipate to a certain extent based on the literature describing ethnographic research of state borders, the humanitarian sector, security and refugees, and which concern limited access, entry permits and research logistics in general, confidentiality, the language barrier, etc. (cf. e.g. Donnan and Wilson 2010; Düvell et al. 2009; Harrell-Bond and Voutira 2007; Hopkins 1993; Jacobsen and Landau 2003; Kość-Ryżko 2012-2013; Smith 2009). We were confronted with new issues when writing up the text; and the one we found most critical was how to avoid normalization generated by the scholarly language and apparatus, i.e. how to, at least to some extent, preserve the gravity of what we witnessed in the text. In this paper, we deal with methodological issues, research methods and procedures that we were employing and testing during our stay at the camp and which we consider an important segment in understanding the camp itself. Doing that we will consciously discipline our experience of being at the camp and our feelings of insecurity, surprise, shock, and constant improvising, fear and helplessness which were our constant companions during the entire period.

\section{ENTRY?}

Bus stations and other places of refugees' gathering in the autumn of 2015 were sites where Croatia's inhabitants could come and go as they pleased. This was even true of green borders where, in response to the immediate situation, border restrictions were largely suspended. In contrast, entry into the Slavonski Brod camp was only possible with official authorization and after multiple checks by the Ministry of the Interior. ${ }^{5}$ Thus, to

arrived every day, with a tendency of decrease, on the level of the entire period. For instance, according to problematic official numbers, on one of the days in January 2016 the arrival of around 3,000 people was registered, whereas on another day of the same month, around 500 persons were registered. On 5 March 2016 the last train arrived in the camp, with some 250 people. This was the only train that arrived in the camp that day.

${ }^{5}$ The camp in Slavonski Brod, like, previously, the camp in Opatovac, was managed and controlled by the Ministry of the Interior, with the Minister (or, later, deputy of Minister) being the head of the so-called Crisis Unit, actually the Unit for the Coordination of Activities Related to the Arrival of Migrants in the Republic of Croatia. The Crisis Unit was founded by the Government of the Republic of Croatia on 17 September 2015 , and its aim was to ensure "coordinated action of all responsible bodies and institutions, with the aim of humanitarian reception and care of migrants" (Vlada Republike Hrvatske 2015). According to the Government's decision (Vlada Republike Hrvatske 2015), the Crisis Unit included representatives of the Ministry of Social Policy and Youth, the Ministry of Foreign and European Affairs, the Ministry of Labor and the Pension System, the Ministry of Health, the Ministry of Defense, more specifically of the General Staff of the Armed Forces of the Republic of Croatia and the National Protection and Rescue Directorate. All these participants, indirectly or directly, to a greater or smaller extent depending on the phase, took part in the operation of the Slavonski Brod camp. However, the Ministry of the Interior played a key role in the functioning of the camp, alongside the Ministry of Health, and the National Protection and Rescue Directorate, which was in charge of the logistical and technical support. Moreover, based on the mentioned Decision which provided for other state bodies and institutions to be part of the Crisis Unit, they were joined by the Croatian Red Cross 
enter the camp as, for instance, a volunteer, a person was required to be a member of, or be affiliated with, an organization that was supposed to obtain prior authorization to be present at the camp, and which could, based on that authorization, submit individual applications for its volunteers. One of us volunteered at the camp in accordance with this procedure in the first weeks upon its opening in mid-November 2015. Not long after that, when a decision was made to conduct research in the camp, the Institute formally requested permission from the Ministry of the Interior for a group of researchers, as stated in the letter, to be granted "entry, movement research conducting privileges in the Reception Center in Slavonski Brod". The application was essentially approved on the same day, and formally approved six weeks later, when the Ministry requested our names, personal identification numbers and photographs to issue accreditation cards for us. Different categories of accreditation cards were being issued at the camp (for public works personnel, volunteers and employees of the Croatian Red Cross, volunteers from non-governmental organizations, etc.). Certain groups and individuals that did not have a role in the camp itself, such as the media or delegations, were given non-personalized daily, so-called onetime accreditation cards. Given the fact that we announced that our research would be of longer duration, which some approaches rightly consider a precondition for ethnography (cf. e.g. Atkinson 2015: 3, 12 et passim; cf. e.g. Clifford 1983: 121-126; Potkonjak 2014: 21-22, 80), we were given personalized, permanent accreditations. However, our accreditation cards, given that there was no special category for researchers, in addition to our names, photographs and numbers, had the label "volunteer".

Fixed classification of accreditations, which was based on the logic of responsibilities and the authorities that certain groups and organizations had, was the first indication of the mechanistic division of labor in the camp, while our application for institutional approval was the first instance where this ethnographic study was different from others dominating the Croatian context. Institutional research approval is, admittedly, provided for in the discipline, and has been integrated as part of research guidelines (cf. e.g. Etički kodeks 2013: II/2), but in practice it is not always sought, because in Croatia, among other things, comparatively few studies are done in institutions. In relation to some other studies which might also involve seeking institutional approvals, seeking approval to conduct research in a camp involved a higher level of uncertainty, as the camp is a closed-type institution under the Ministry of the Interior jurisdiction (cf. e.g. Wacquant 2002: 387). Similar research is rare in the Croatian context; one example relevant in the context of institutional approval is the research into the Lepoglava Panopticon, the Lepoglava prison, where the permission from the competent ministry was also sought (Đurin 2011). The application of the researcher, Sanja Đurin, was not approved, and she conducted her

(cf. Larsen et al. 2016: 12-14), which "took care of distributing food, water, clothes and hygienic products and provided psychosocial support and reconnecting families services" (Hrvatski Crveni križ 2016: 6). The Croatian Red Cross was also in charge of "coordinating all organizations that provided humanitarian aid to the refugees and migrants" (Hrvatski Crveni križ 2016: 6), which included intergovernmental, international and Croatian agencies and non-governmental organizations present at the camp. 
research, which consisted of "interviews with two prisoners" and observation "based on visiting one of the prisoners", "without any official approval" (Đurin 2011: 270). Personal acquaintance with one of the prisoners and obtaining his consent for participation enabled Đurin to conduct the study which, only if viewed from a bureaucratized and institutional perspective, could related to covert research familiar from ethnographic literature (cf. e.g. Allu Davies 2001: 53-58).

In order to understand the similarities as well as the differences in the degree of inaccessibility between the prison and the camp, one should note that "institutionally covert" research in the prison was possible because the researcher could take on the role of a visitor, whereas, in order to conduct a similar type of study in the camp, one should secure a practical function such as a volunteer, interpreter or some other, which is what some researchers resorted to in other countries having been faced with the difficulties of obtaining an institutional permission (e.g. Agier 2015: 65-66; see also e.g. Harrell-Bond and Voutira 2007: 283-288). ${ }^{6}$ As has been said, we conducted our research in the camp for a longer period of time with institutional approval, and we mostly formally entered the camp as researchers.

Given that our initial motivation was to support refugees and their movement, and given ethnographic methodological inclination towards "participant observation" (cf. e.g. Atkinson 2015: 34-35, 39-41 et passim; Potkonjak 2014: 68-71; Spradley 1980: 53-62), the ethnographic participant role that we adopted in the camp was that of volunteers of one of the organizations in the camp.? It was only exceptionally, when we conducted scheduled interviews with camp employees, when we recorded using a camera or when we openly took notes as we observed (cf. e.g. Emerson et al. 1995: 20-26), that we were not in the camp in the role of volunteers.

\section{OBSERVATION?}

In accordance with the contemporary migraton regime based on the "politics of insecurity", which categorize "undesired" foreigners as asylum seekers, foreigners residing illegally

\footnotetext{
${ }^{6}$ In their works on this and similar topics, Croatian ethnologists do not address institution access, as is the case, for instance, in the research concerning the Reception Center for Asylum Seekers in Zagreb, the so-called Porin Hotel (cf. Petrović and Pozniak 2014; also cf. Petrović 2016: 400-416), or when they do address it, as for instance in the case of the Opatovac camp (cf. Čapo 2015a: 391), the provided permission is "a permit for entry and brief stays at the reception center over several days" (Čapo 2015a: 391), which means not for longterm ethnographic research, but for "guided tours" like those organized for media crews (cf e.g. Hina 30 October 2015 "Reportaža iz Opatovca: Ništa nam ne daju, ali neka znaju da Bog sve ovo vidi”, http://www.index.hr/vijesti/clanak/reportaza-iz-opatovca-nista-nam-ne-daju-ali-neka-znaju-da-bogsve-ovo-vidi/852662.aspx).

${ }^{7}$ Given that we were authorized by the competent Ministry to do research in the camp, we were exempt from the norms of the organization that we volunteered for, according to which volunteering in the camp included only supporting the refugees and working within the framework of the organization, but not doing independent or public work, as journalists, researchers or in any other similar way.
} 
on the territory of a certain country, asylees, etc., and which physically separate them from the other population (Huysmans 2006; also cf. e.g. Walters 2004; Wilsher 2012: 171-206), Croatia at that time, just like today, was striving to minimize contact between refugees and Croatian citizens. The argumentation for this in the public discourse, which was adapted to the initial reactions which were, nevertheless, empathic, was based on the standard images of refugees as a potential health and safety threat, as well as the premise of refugees as a potential infrastructural (e.g. traffic-related) threat, or some sort of obstacle. ${ }^{8}$ The results of this endeavor, echoing the statements by some politicians, were emphasized as one of the unquestionable signs of the success of Croatian refugee politics. As initial preparations were made for the opening of the Slavonski Brod transit center, the then Minister of the Interior, in an effort to placate the local community by promising that the camp will not cause any changes, made the following statement: "This means that there was not a single person at any time, except for those suffering from hallucinations, who has ever seen a single refugee in Croatia other than in Opatovac, and no one will see them in Slavonski Brod either." ${ }^{9}$ With the Slavonski Brod camp, this ambition and promise was fulfilled. When we talked about the reactions of the local community to the news about camp construction, our interlocutors said:

People do not see the migrants at all. They are simply in passing here, they leave by train, nobody, I do not know if anybody has ever seen them, and then said: yes, I did see them. Perhaps someone saw the train with the migrants, but that is nothing special. [...] [The railway line], you could say, goes through the town, it actually goes through the town, but there is no contact with people, really. [...] so that this is, really ideal, convenient.

As mentioned by Duško Petrović in the chapters where he interprets the Slavonski Brod camp in the context of securitarian humanitarianism (2016: 391-416), the camp was outside the town, in the industrial zone, on the grounds of the former refinery, outside the main town street grid and beyond the reach of public transport. Even when taking into consideration the railway line - which seemed like a direct connection to its surroundings - the camp was, in fact, isolated. The railway line ended in the camp with a dead-end track, and only trains with refugees under a police escort would go there. Enclosed by natural and man-made obstacles, a river and a fence, the camp was connected with, and additionally isolated from, the environment via the accreditation system, as well as entry checks, which changed through time depending on a variety of subjective and objective circumstances. Government officials, employees, volunteers and others entered the camp through the central road entrance where, in the shade of the building which was police and camp headquarters, there was a container where the accreditation cards were checked

${ }^{8}$ For recent studies into attitudes about, for instance, asylum seekers in Croatia, for the period before the one addressed here, cf. e.g. Gregurović, Kuti and Župarić-Iljić (2016), Gregurović and Župarić-Iljić (2013), Župarić-Iljić (2013), Petrović and Pozniak (2014).

${ }^{9}$ Hina, 14 October 2015. "Ostojić odbacio kritike iz Slavonskog Broda: Haluciniraju oni koji izbjeglice vide van Opatovca”, http://www.index.hr/vijesti/clanak/ostojic-odbacio-kritike-iz-slavonskog-broda-halucinirajuoni-koji-izbjeglice-vide-van-opatovca/848146.aspx. 
and an X-ray and metal detection inspection were performed. Starting in February 2016, when the camp was less and less a place of transit, and more and more a place of forcible detainment, detention, this was the place where written records of entry and exit were kept. Starting with 18 March, when the camp manager granted all organizations access to the closed detention sectors of the camp the organizations had to give individual names of the already accredited employees/volunteers, who, in addition to being registered on entering the camp, were also registered when entering particular sectors, not only by the Ministry of the Interior employees, but also by the employees of the Red Cross.

Moreover, the camp was crisscrossed by numerous physical and visible as well as invisible borders on the inside, which separated accessible from inaccessible areas. The accessibility of certain parts of the camp to volunteers, employees and others depended on which group they belonged to and, particularly in the case of larger organizations, the function they had in the organization. As researchers, when we were given permission to conduct research in the camp, we did not receive any guidelines or instructions as to access or lack of access to certain parts of the camp, as to the use of audio-visual equipment, etc. The field guide of the organization that we volunteered for (Inicijativa Dobrodošli 2015) said that its volunteers had no access to the "pre-registration section" during transit, and given that one of us had volunteered in November 2015, we knew that, like most volunteers and employees of humanitarian and related organizations, we had no access to the registration tents or the inside of the train. Shortly before our first visit to the camp as researchers, we heard whispers, which later turned out to be true, that there are "guarded areas" in the camp, which included areas "from registration to the infamous sector" where refugees who were temporarily or permanently forbidden further travel were being detained i.e. who did not pass the so-called profiling, selection and discrimination control measures used by the police of the countries along the corridor from November 2015 until its closure. ${ }^{10}$

With the exception of the restrictions from the field guide, and signs forbidding photography and video recording, which became more numerous and noticeable with time, we largely learned about the other restrictions in the camp gradually, by word of mouth. In early February, upon leaving the fifth sector - a part of the camp that we had regularly visited until then, accommodating people who temporarily stopped their journey to, for example, wait for a family member kept for medical treatment - we were given the following instruction in a chance encounter with a volunteer of another organization: "You may enter

${ }^{10}$ Profiling was done systematically starting on 18 October 2016, when Slovenia and Croatia extracted the first groups of refugees that did not come from Syria, Iraq or Afghanistan (cf. Inicijativa Dobrodošli. 19 October 2016. "Nedopustivo je odvajanje izbjeglica na one koje su iz tzv. ratnih zona i na ostale", http:// welcome.cms.hr/index.php/hr/2015/11/19/odvajanje-izbjeglica-na-one-koje-su-iz-tzv-ratnih-zona-ina-ostale/; Moving Europe 21 January 2016 "Restrictions and segregation on the Balkanroute: Fences, Detention and Push-Backs", http://moving-europe.org/restrictions-and-segregation-on-the-balkanroutefences-detention-and-push-backs/\#_ftnref1). To find out about the chronology, ways and effects of ethnic, linguistic and other type of profiling, i.e. segregation along the corridor, see the reports: Banich et al. (2016a and 2016b); Inicijativa Dobrodošli (2016) and Moving Europe (2016). 
the fifth sector only if accompanied by a Red Cross volunteer, and you may not enter the third sector at all." Restrictions on entering the third sector i.e. the parts of the camp where refugees who had not passed the so-called profiling were continually detained, were given verbally and informally for weeks, and were officially formulated in mid-February. The following message was given at a coordination meeting between the Croatian Red Cross, non-governmental organizations and similar organizations in the camp: "The third sector is open only to the police and the Red Cross, all others who approach it will be arrested and their accreditations will be taken away." This was worded a bit more moderately in the Notes from the Coordination Meeting of the NGO/INGO/IO in the Winter Transit Reception Center in Slavonski Brod of 8 February 2016: "CRC [Croatian Red Cross] is allowed to enter the sector 3 by the call of the Police, and no other organisation can enter the sector 3. If anyone tries to enter the sector 3 , he will be processed by the Police."

Furthermore, knowledge concerning restrictions would often be transmitted by imitation and indirectly, which was the case when, during our first tour of the camp, we were shown places where volunteers of non-governmental organizations stayed and worked during transit, simultaneously suggesting that we had no business being in any other places. This type of regulation of movement through space, but to a much greater degree, also applied to the refugees. Following only sporadic signs and circular pathway formed by the entrances, exits, fences and the physical positions of police officers, the refugees moved through the camp primarily by imitating each other, and would learn about the rules for moving along the route only when the police, sometimes accompanied by yelling and a certain hostility for having to state the obvious, would warn them that they were breaking the rules.

Thus, although we were faced with a growing number of bans and restricted areas, some of these areas, although they were out of bounds, were becoming less of a total mystery with time. We constructed our images of and insights into these spaces in different ways, including, in a manner of speaking, direct observation, but having to significantly modify this ethnographic method (cf. e.g. Potkonjak 2014: 69). For instance, one of us was part of a group being given a tour of the camp organized for the new Minister of the Interior, and went through the registration tent, the place where key activities for the continuation of the refugees' journey, ${ }^{11}$ took place, which was not operational at the time. Given the great speed with which the Minister and his entourage went through the camp, including the registration tent, it was impossible to get a good look of the inside of the tent. This is why, in this particular case, rather than using the technique of longer unobstructed observation where one tries to notice details from the specific research point of view (cf.

\footnotetext{
${ }^{11}$ According to its key characteristics, primarily the practices of registration, control, selection, reception, admission or expulsion that were operationalized in registration tents, the Slavonski Brod camp is partially comparable to other contemporary places where refugees are concentrated, more specifically with the type of places that Michel Agier (2015: 46-52) refers to as refugee sorting centers. Such places, in contrast to self-organized "camps", are under direct control and management of national administrations, the police or UN agencies and/or humanitarian non-governmental organizations. They are transit spaces where the mentioned practices of selection are carried out, and staying in them implies shorter or longer periods of immobility, waiting and coercion.
} 
e.g. Emerson et al. 1995: 26-27; Potkonjak 2014: 70), we could only apply techniques of rapid scanning of the area, which could literally take only several seconds, the time it took to walk through the tent.

Similarly briefly entering railroad cars, which we were granted ad hoc permissions for on several occasions, also included rapid, in this case prominently participatory, rather than observational scanning, which differed from the previous case also because of its, tentatively speaking, ethnographic insight potential (cf. e.g. Atkinson 2015). As opposed to the hurried protocolary "visit" to the registration tent, which was reduced to a mere stage set at the time, our short visits to railroad cars generated strong impressions, and had a significant impact on our understanding of the camp and the transit of refugees. The image of the overcrowded railroad car, completely blocked by people, which was, as we could sometimes hear, "being loaded" with double or nearly double the number of passengers than was standard in regular transport, for us became a visual synecdoche for the policy of dehumanized efficient transit.

In addition to the special cases, like the ones mentioned, where certain spaces were accessible by permission, some other areas, where we could not enter, were accessible through what we will refer to as external observation. Occasionally, albeit rarely, during registration procedures, the entryways to some registration tents were left open, which made the inside of the tent, as well as the events that took place there, relatively accessible to us as external observers. Our fieldnotes show how partial an insight this sort of research situation provided:

registration tent is open (tent flap up) and you can see inside, but the sunlight is strong and I cannot see very well; a police officer exited the tent, he has a mask on, there is a wheelchair inside, I can see a woman holding a child on her sitting in a chair in front of a desk (I cannot see the police officer interrogating her on the other side of the desk because my view is blocked), several police officers are walking around the tent, I see one Red Cross uniform.

Similarly, both times that we were allowed to photograph and record the arrival and departure of the refugee train, with an unobtrusive but present accompaniment of a police officer, when walking around those parts of the camp that were normally accessible to visitors (journalists), we used zoom to try to take photos of the spaces that we had no access to otherwise, such as the area in front of the entrance to the registration tents, as well as people who we could not access in person because they were detained in one of the camp sectors.

External observation, including taking photographs, was not as time-restricted as scanning the inside of the registration tent or the train, but it was interrupted by other actions meant to camouflage our primary purpose to see what was attempted to be hidden from view. Rather than making this seem like careful observation, looking towards the tent and its interior was meant to seem coincidental. Rather than seeming like targeted, focused recording and photography of areas and people that we had no access to, this was meant to look like recording "permitted" scenes. 
What was at play here, like in some other cases, was to some extent interiorization of prohibitions central to the camp's functioning. Although looking towards the tent or zooming in were not prohibited, we perceived the prohibition as being there or as being conceivable. Similarly, although the orally transmitted prohibition to enter registration tents did not specify time (whether it only related to the occasions when registration took place, or was meant to be absolute), we perceived it as constant, and we entered the tent only several times, exclusively under police escort or with police permission.

This unwritten nature of the rules and prohibitions was accompanied by a considerable dose of uncertainty as to what was allowed and what was not (which meant that sometimes things might have been perceived as not allowed, whereas they might have been), however it equally allowed transgressing some boundaries which would have been difficult to cross if restrictions had been given in writing. For instance, the platform where the trains arrived and departed from, and which was divided from the rest of a camp by a fence as a clear border sign visible to all those in the camp, was the place of minor but constant disagreements when the trains were leaving. Every now and then, volunteers from some organizations would cross the border, when helping people to carry their luggage or when taking blankets to people who were on the train waiting for it to depart. After this process repeated several times, camp management responsible for the humanitarian support of the camp would issue an instruction or a prohibition not to approach the platform. The volunteers would abide by the instruction for a while, and would again, at one point, go to the platform, which could be described as a moment of small rebellion against camp rules, and then the entire process would repeat.

The interiorization of prohibitions and rules is also evident from some methodological decisions we made and steps we followed, including sound recording. Experimenting with note-taking methods which could be considered somewhat alternative in the Croatian context, wanting to reach different levels of the camp, we used a sound-recording device several times to overtly record the sounds in the camp (cf. Atkinson 2015: 146-147 et passim; Ehn et al. 2016: 85), particularly the first several minutes of the arrival and departure of the train. However, in mid-March, in the weeks before the camp was closed, when several hundred persons were detained in the camp and when only a handful of volunteers and employees had access to them, we "covertly" used a sound recorder. One of us recorded the distressing sounds of nearly one-hour-long screams and shouts of a young man who resisted collective transfer of "single men" from the third to the first sector of the camp, by keeping the recorder running in a jacket pocket. In our daily report from the camp to the organization that we volunteered for and to another organization that published daily reports about the situation in the field, one of us gave the following description:

After the police led twenty or so men, forming two lines, from Sector 3, they literally carried a younger man out [...]. Holding him by his arms and legs, they carried him in a vertical position from Sector 3 to [...] the first tent in Sector 1. [...] Those of us who do not have access to the sector could not see what went on in the tent, but loud screams, shouts and intermittent knocking sounds were a sufficient indicator of the state the man 
was in. Although one could not understand the meaning of the shouts, it was clear that they were a call for help. Many referred to his behavior as a nervous breakdown.

Although we had not come upon an explicit or implicit prohibition of sound recording in the camp, and although we had indeed, as we said, made overt recordings using a voice recorder on some occasions, we did not consider overt recording to be a viable option under these circumstances, to some degree as a result of a previous research situation. To wit, some ten days earlier, we had decided to walk around the entire perimeter fence of the camp and make notes about the camp from this perspective. When we walked around the camp, i.e. outside the perimeter fence, where there were no signs whatsoever prohibiting photography, we also took photographs, which is why a police officer on duty in that area demanded to see our ID cards and sent us, as we were told, to the camp manager. The police officer did not take us inside the building, but we stood in front of the building, next to him and alongside other people who happened to be there, when higher-ranking police officials, who did not identify themselves to us, addressed us with a dose of mockery, followed by accusatory and threatening remarks. We deleted the photographs at the request of one of them, and then, after we had been vouched for by a colleague of his over the phone, we were let go with a warning: "This is the first and the last time you do that. Do it one more time, and you will lose your accreditation." This is the time when we could very directly experience the camp as a place of uncertainty and fear, and the suspension of one's rights. From a research/volunteer perspective, having one's accreditation revoked was the most extreme suspension possible, but chance had it that we witnessed a glimpse of its true scale with regard to the refugees at the very same occasion for the first time. As the police officer took us to the police building via a shortcut that we had normally no access to, we had the opportunity to quickly "externally observe" the third detention sector, that we only had sketchy information about. We were able to see detained and isolated persons: "In sector 3 all containers full, lights on. The face of a woman, some 20 years of age, looking towards us, as the policeman leads us on. there are also people in the white tent in sector 3."

\section{INTERVIEWS?}

Since the opening of the camp until the official closure of the corridor on the night of 8 March 2016, the Slavonski Brod camp primarily had a transit character. This is the period when the refugees were brought to the camp escorted by the Croatian police, mostly by train, from Šid, Serbia. They underwent the process of registration in the camp, and would then be returned to the train that would go on its way to Slovenia. Occasionally, more frequently at the very beginnings of the camp's operation, they would be held for several hours in those sectors intended for accommodation.

In order to make transit as quick and efficient as possible, contact between the refugees and the volunteers in the camp was limited, even during the short period of several hours 
when the refugees stayed at the camp or, rather, went through it. As opposed to the previously mentioned attempts to minimize contact between refugees and the citizens of Croatia, clear and highlighted in political statements, no explicit mention of this was made in official statements or interviews that we conducted with camp management representatives. However, this was evident from the organizational characteristics of the camp, primarily its clear division into areas, such as refugee sectors, stock areas, management and volunteer headquarters and the like, ${ }^{12}$ as well as from the strict circular route that the refugees in transit were supposed to take in the camp. During the time that we were at the camp, this route began with the refugees exiting the train, continued with their passing through registration and distribution tents, with possible hold-ups, for instance, in the mother-and-baby tent or at the kiosk, and then through the access road to the platform, ending in their entering the train. Each of the mentioned points was connected with a separate type of activity, and a separate group of volunteers or employees worked at each of the points, e.g. helping to get off the train, checking things and personal data (i.e. registration), distributing clothes and footwear, distributing food, helping to get on the train, etc. Fragmentation and automatization of activities, where each individual dealt with a single segment in the entire process, created an impression of working on a conveyor belt. As far as volunteers from non-governmental organizations were concerned - which was the group that we belonged to - the only place designed to meet with the refugees during transit was the distribution tent, which was, however, given its purpose to distribute clothes and footwear as quickly as possible, never intended as a point where interactions other than those of supply and demand would take place, which did not imply that other interactions could not develop on some occasions (cf. Jambrešić Kirin and Škokić 2016). This organization of transit meant that there were very few opportunities for ethnographic research directed towards the thoughts and experiences of refugees, that would be based on in-depth interviews as the basic technique of their "collection" (cf. e.g. Potkonjak 2014: 71-76; Sherman Heyl 2007). Such interviews, had there not been for access restrictions, could have been conducted with the refugees in the closed sectors, where they were held for shorter or longer periods of time.

However, even when all volunteers and employees were given access to the closed sections under special conditions (this was during the exclusively detention period, but not until the second half of March, as already mentioned), we did not conduct interviews for numerous interrelated reasons, many of which would have applied to the previous, largely transit, period. The reasons varied from the impossibility of clearly presenting our role as researchers, and complete inequality in the potential relationship between the researchers

12 The Slavonski Brod camp spanned an area of about 40,000 square meters, and was divided into six sectors designed for the accommodation of refugees (Puljizević 2015), with a tent and container infrastructure which could house 5000 people (Larsen et al. 2016: 10), and the main building, infirmary, tents for the army, tents of the National Protection and Rescue Directorate, a brick-built Red Cross warehouse, a tent warehouse, containers with offices of non-governmental, inter-governmental and other organizations, a tent mess for volunteers and employees, registration tents, tents for vulnerable groups or special types of assistance, distribution tents, etc. The layout of the mobile objects and their purpose changed several times. 
and "the researched", through our lack of knowledge of the languages relevant for such research (Kurdish, Arabic, Persian etc.), our unwillingness to dedicate the very short time that we had at our disposal in the closed sectors to documenting ethnographic statements, to the fear of secondary traumatization of the refugees and the likely devastating consequences this might have for them in their present environment. If we had been able to surmount any of these obstacles, and if we had decided to do in-depth interviews, we believe that we would not have recorded them, primarily because of the hazard of endangering the detained persons simply through their participation in recorded interviews, and particularly because of the danger of potential unauthorized access to them, which is a topic that crosses over into general problems of ethnographic methodology, ranging from the confidentiality between the researcher and "the researched" (cf. e.g. Allu Davies 2001: 51-53), to the problem of research topics that contain elements of illegal activities (cf. e.g. Potkonjak 2014: 37).

Given all this, we conducted recorded interviews in the camp only with people on our side of the ramp that divided the refugees from all the others, which almost exclusively included persons in official positions, generally of high rank or uniquely connected with the functioning of the camp: police employees, Croatian Red Cross and army employees, healthcare workers and employees providing other services in the camp. These interviews were meant to familiarize us with the operational management visions of the camp, its conceptual design in terms of its construction and operation, its organization, structure, management structure, etc.; i.e. those segments of the camp that were not available to us on the experiential level from our volunteer-participant position (cf. Hammersley and Atkinson 1996: 125). These interviews, it should be mentioned, were not preceded by getting to know our interlocutors or building some sort of rapport or even intimacy with them, and the interviews themselves, to some extent because of this, did not have a pronounced personal level, i.e. they did not have some of the characteristics that are commonly associated with the ethnographic interview (cf. Potkonjak 2014: 73; Sherman Heyl 2007: 369). Given that, as far as the management aspect of the camp is concerned, our participant position was absent, and insights from observation were reduced to a minimum, some would claim that these interviews could not even be referred to as ethnographic (cf. Atkinson 2015: 12, 92-94 et passim). This means that the very act that most clearly defined us as researchers to others, and that we ourselves saw as a sort of confirmation of our role as researchers to the management structures, had much less ethnographic value for us in comparison to the other methods that we used.

In line with the roles that our interlocutors had in the camp, and in line with their prevailing status of official representatives of their institutions, their positions voiced in the interviews had a spokesperson-like quality to varying degrees. Some of them officially held the function of spokespeople, and others implicitly presented themselves as the spokespeople for their institution or the entire camp, and even as spokespeople for Croatia, a country that, according to the interpretations dominating in these interviews, proved to be particularly humane, and even the most humane country in its treatment of the refugees. For instance: 
In every group that arrives here at the camp all you can hear is the following: Thank you, Croatia, thank you for the love, for the support, for the help, etc. [...] Croatia, this small country with a small number of inhabitants in relation to any other country, but a country where the people are warm and willing to help.

According to these statements, humanity was reflected on two levels: the level of the treatment of refugees by the people of Croatia, where, like in numerous media and other statements (cf. e.g. Čapo 2015b: 16-17), the Croatian refugee experience was stereotypically mentioned as the source of such treatment, and the level of the functioning of the national government, which, as it was stated in the interviews, was most clearly visible in the nearly flawless functioning of the camp itself. For instance:

We have a heap of newspapers, delegations, this or the other every day, and to be honest, all those who were here were at a loss for words at how well all this is organized, structured, made [...] no other country on the route has anything similar to this [...].

"Flawless functioning" of the camp was also one of the first things, which may have been left unsaid or only hinted at in our conversations, where we disagreed with our interlocutors. Apart from the fundamental disagreement in seeing camps as, on the one hand, an expression of humanity, and on the other as humanitarian oppression, these disagreements were related to the fact that, in the camp, we witnessed behaviors such as pushing, shouting, unnecessarily stopping people or making them move faster, separating families or groups that traveled together, forceful, sometimes several hour-long detainment on the train before its departure, overcrowding railroad cars, not giving assistance to the freezing people in the unheated train waiting for its departure, withholding information, verbal insults that remain insults even if the person at whom they were directed did not understand them. After all, rather than "Thank you, Croatia" that we mentioned above, several times in the camp we heard statements like the one recorded in our fieldnotes: "We are not animals. Why do you treat us like that?".

In our interviews, we only minimally questioned the image that our interlocutors created in their answers, which was also the foundation of the media image in Croatia, that some of our interlocutors also actively participated in creating, given the function they had. Not only did we not come into conflict with our interlocutors, we also avoided some sub-questions and moved on to other topics when we started seeing cracks in the nearly perfect images of the Slavonski Brod camp and the Croatian version of refugee reception, even in those cases where, on the basis of our participatory research experience, we could see or assume that what had been said did not correspond to reality. This was not only a matter of following the fieldwork manual instruction, which is the result of the nature of the ethnographic interview, where the researcher should not come into conflict with his/ her interlocutors, and should let them talk about what they consider relevant, in a way that they want, and not to talk about what they do not wish to, cannot, or are not permitted to discuss (cf. e.9. Potkonjak 2014: 73-75). From a post-hoc perspective, it can be said that our behavior was also influenced by our fear that our reactions and questions during 
the interview could jeopardize our future stay at the camp, by, for instance, restricting or interfering with some of our activities, either as volunteers or researchers (cf. e.g. Hopkins 1993: 125; Kość-Ryżko 2013: 238). The explanation of our, as we see it today, servility towards our interlocutors, could be applicable on a higher level, that of the behavior of the organizations in the camp. According to our insights, they came only into minimal conflict with the management of the camp, or avoided conflict altogether, which we in the case of organizations which were not part of standard humanitarian intervention teams - attribute to the continued fear that their reaction could result in loss of access to the camp, and, conversely, the prerequisite for providing direct aid to the refugees, and the prerequisite for - at least to some extent - monitoring what was going on in the camp, giving them at least some - however slight - opportunity to intervene.

The fact that, in the end, we only conducted interviews with official and institutionally appointed camp representatives, but not with people who were excluded from the decisionmaking process, and who were only minimally familiar with it, such as volunteers and lower-ranking officials, was also influenced by some factors other than our interest in management and other dimensions of the camp that we - in contrast to the dimensions that we had access to as participants and observers - could not discover through participation.

This primarily refers to the combination of what we identified as the unwillingness of our potential interlocutors to share their thoughts with us in a formal recorded interview, and the real implicit or explicit negative reactions of those few that we had our first contacts with. In addition to an entire array of possible purely individual causes for such reactions, well known from other ethnographic research (cf. e.g. Bošković-Stulli 1998: 273), other causes, which are well known in ethnographic research into business organizations, etc., could be mentioned (cf. e.g. Hammersley and Atkinson 1996: 127-128). Some of the organizations present in the camp, as we were told, had their employees sign contracts stipulating that they were not allowed to give statements about their work or the work of the organization in question. According to some information, this rule was sometimes only given orally or was tacit, i.e. it was the volunteer or employee who inferred that their statements could in some way cause damage to themselves or to the organization they worked for. For instance, this is suggested by the reaction of a volunteer, whose volunteer status was supposed to change to that of an employee when we were at the camp, which may not be insignificant in itself. Although we preliminarily scheduled a conversation with her during our first stay at the camp, when we suggested to meet again, she texted us - although we had not ask for this piece of information - the name and mobile phone number of her superior that we could or should talk to, thus letting us know not only that she did not want to take part in a recorded interview, but that she wished to avoid any meeting or potential conversation whatsoever. An agitated and even angry response from a manager of one of the organizations in the camp, upon finding out in casual conversation that one of the lower-ranking employees had talked to the researchers, was also indicative of the management's attitude towards the possibility of unmonitored transfer of information or attitudes of people working in the camp (or transfer that was not agreed through the so- 
called official channels). In summ, just as the camp was replete with visible and invisible borders, it was replete with visible and invisible gatekeepers (Hammersley and Atkinson 1996: 63-67, 133-135; Potkonjak 2014: 94). Just as the borders blocked access to certain areas and ethnographic observations, gatekeepers, in one way or another, explicitly or implicitly, blocked access to people and interviewing them.

On the other hand, as far as accessing volunteer perspectives in the camp or about the camp is concerned, it is true that we could have conducted recorded interviews with the volunteers of those rare non-governmental organizations in the camp which were not primarily part of the so called humanitarian business (cf. e.g. Belloni 2007; Weiss 2013). We assume that at least some of these volunteers, given their independence of financial or other specific obligations to the institutions, and depending on their general openness to sharing and disclosing information and perspectives, would have shared with us their thoughts in recorded interviews, just like they had done in everyday communication in the camp. However, the growing complexity of our insights into the camp and what was happening in it, the final closure of the corridor and the conversion of the camp into a detention camp, led to a shift in our priorities towards other research focuses (particularly towards closed parts of the camp), other interlocutors and other methods. This led to leaving out the planned recorded interviews with non-governmental organization volunteers focusing on their experience and understanding of the camp and their work in it, as well as recorded interviews with persons who did not work in the camp but had indirect insights and opinions about the camp or about its position in the life of the town, for instance because of the fact that they lived in Slavonski Brod.

In conclusion, if we look at our interviews overall, both those that we conducted and those that we did not, one can observe a fact which may seem paradoxical at first sight, and which is significant for the understanding of the camp and the possibilities of conducting ethnographic research in it. On the one hand, as researchers in the camp, we had relatively unobstructed access to the environment of the humanitarian, and, to some extent securitarian, let us call it proletariat and precariat (volunteers, translators, police officers, etc.), but we basically had no access to documenting their statements through recording them. On the other hand, the entire humanitarian securitarian management of the camp was largely outside our observational scope, but access to documenting the institutionally verified statements from this aspect was basically easy. Therefore, it could be said that in our case the permission to conduct research in the camp was in fact a permission to enter the camp, but not to freely access all its spaces and structures (cf. e.g. Harrell-Bond and Voutira 2007: 288), in the case of the former, at least not through interviews.

\section{PARTICIPANT OBSERVATION?}

Although we did not conduct ethnographic interviews in the narrow sense in the camp, while we were there we participated in a number of communicative interactions of 
various durations, modes and languages, that were a constituent part of our ethnographic research, i.e. its key segment: participant observation (cf. e.g. Atkinson 2015: 39-41 et passim; Potkonjak 2014: 68-71; Spradley 1980), in the various nuances of its basic articulations (cf. e.g. Hammersley and Atkinson 1995: 99-113). Given the mentioned radically reduced possibilities of longer contact with refugees in transit, our communication primarily consisted of shorter spontaneous verbal exchanges. These included numerous very short or somewhat longer, although mostly only several-minutes long, conversations in English or in a combination of English and nonverbal signs, with several Persian or Arabic words. They were led during the short walk to the platform, at one of the points along the way or on the platform itself, and included exchanging basic information, on the one hand, where from and where to a person was traveling, with whom, how long they were on the road, and on the other, about the procedure in the camp, the next country or stop along the way, the time it would take the train to get there, etc. We have forgotten the details of many of those conversations, or, more specifically, we remember them only as part of the overall spoken communication, and we remembered some of them, with more or less details, in the form of mental notes (cf. Ottenberg 1991: 144-146) or recorded them in jottings like the following: "Ibrahim and his sister - in front of the toilet. grandfather tells us that their parents were killed." Dumbfounded at the very fieldnote, today we can only relate it to another fieldnote based on a short conversation, that indicates the extent of the suffering, danger, concern and uncertainty that the people running away from the war had to cope with on their way:

I am carrying a bag for a mom (Iraq) (she is young) - limited English, but enough to get by, holding her son by the hand, he is ill, he was running a fever last night, her husband has been in Germ. since Sept. I ask if they saw the doctor, no, train, train (as if they told her that), I tell her that she can stay until the next train, she says - her family is with her I say - family too can stay no no the boy (3-4 years of age) walking next to her, I come closer, he looks as if he's staring into blank space. on the way to the platform she asks me several times if I think she will be able to get to her husband? I hope so I hope so.

This grim and chaotic verbal interaction, chaotically recorded, as a later multilingual, both Croatian and English ${ }^{13}$ transcript of dialogic clips combining narration and direct and indirect speech (cf. Emerson et al. 1995: 74-77), but rather than this impeding understanding upon later reading, it rekindles (at least to some extent, like many of our other fieldnotes do in different ways) the chaos and the gravity of the situation that it represents.

Large concentration of speakers of different languages in a way encouraged everyone in the camp, including us, to communicate in a foreign language or completely (or at least partially) nonverbally, which was related to a relatively small number of interpreters hired to work in the camp. We asked for their assistance only when we assessed a situation as "a crisis", i.e. when it was potentially related to a health issue, separation of the family or something similar, and when we could not establish at least minimal communication

${ }^{13}$ This fieldnote was written in Croatian, with certain English words which are italicized in this translation. 
ourselves. Pointing to someone's luggage, rather than, or accompanied by, a verbal offer of help in carrying their things, pointing the way to the train, pointing to parts of the body to refer to clothing items or footwear that someone may need are only some of the examples of communication during transit, where the nonverbal component dominated over the verbal in communication.

Our "conversation" with an elderly man from Afghanistan whom we met in front of a container in the fifth sector is an excellent indication of how great the potential of nonverbal communication was. He shared with us, as we understood it, his frustration with the fact that he was detained in a camp and that he could not exit the small fenced-in space inside the sector, and shared part of his experience on his refugee "trip" before coming to the camp in Slavonski Brod. By combining different sources - what we were told by a police officer standing guard next to the fence, what we later learned from the translator, and our previous information about this sector - we found out, among other things, that our "interlocutor" was a member of a family that, like many other families during transit through the Slavonski Brod camp, was waiting in the enclosed and monitored sector for a member of his family to come back from the hospital in order to continue on their way. Our "interlocutor" "told us" - speaking in a language that we could not understand, but still using several words that we could catch here and there ([Yunan] for Greece), and using his hands and gaze to show the fence in front of him and the area surrounding the camp, the police officer that was "protecting" him, and, particularly, by scrolling on his mobile phone and showing photographs and video clips recorded earlier - that he and his family lived in Greece for a period of time, in an apartment owned by a Greek doctor and his family, that he was a guest there, that he could move freely, and that he was closed up here, without the possibility of moving even around the camp which was closed away from the outer world. The photographs and video recordings on his mobile phone were his travel (refugee) diary, where he finally added our photographs that he took after using a gesture to ask our permission, and this diary helped him, in spite of the language barrier, and with considerable effort, to convey to us what he wanted.

As opposed to communicative situations like the one just described, which we participated in during our entire stay at the camp, some communicative situations characteristic of the camp environment were more closely or exclusively related to the phase when the dominant function of the camp was transit, and others were characteristic of the phase when the camp had an exclusive detention function. Upon the closure of the corridor and the termination of transit through the camp, the short communication exchanges on the circular pathway break off completely, whereas other types of direct interactions between volunteers and refugees, because of no access to the closed sectors, did not start for days.

When we, and others in the camp, were given access to these sectors for several hours a day, after the publication of the Izvješće o sustavnom kršenju ljudskih prava $u$ zatvorenim dijelovima Zimskog prihvatno-tranzitnog centra u Slavonskom Brodu Report on Systemic Human Rights Violations by the Croatian Authorities in the Closed Parts of 
the Winter Reception and Transit Centre in Slavonski Brod on 16 March 2016 (Banich et al. 2016b) and a day after "single men" were transferred from one closed sector into another, our communication patterns changed. From then until the closure of the camp, we communicated with a much narrower circle of interlocutors in relation to the transit period, but the communication became more complex with regard to its content and forms. At first it consisted of short conversations which boiled down to the informative level, regarding the conditions of return and detention, the options for leaving the camp and the Croatian and European system of asylum, and later we primarily talked about "everyday topics", that related not only to our present and past, but also their future life outside the camp in Croatia or elsewhere, which was, at that point in time, completely uncertain.

These conversations generally took place "on the go" on a gravel plateau in front of the tents and containers, but we would also sometimes "visit with the people", when we were invited for a conversation into one of the containers, or when people would move to provide room for us to sit on one of the benches in the sector. Although our conversations were still mainly fragmented, and based on verbal and nonverbal exchanges, multilingual and in a foreign language, all of them - the shorter and the longer once - were generally not single-time affairs. Several words exchanged during one visit to the sector were built upon at a next visit, and one interlocutor or group of interlocutors would lead, as is usual, to other interlocutors, and would bring about new acquaintanceships, some of which lived on, and sometimes even deepened, after the closure of the camp. It was these very acquaintanceships - which we had a chance to continue - that indicated how basic our communication in the camp was. For instance, it was months after the closure of the camp, that we learned that, in addition to people excluded from the corridor - those who were returned from Slovenia or detained in Croatia (cf. Banich et al. 2016b), there were also several people detained in the camp, who were previously deported to Slovenia from Austria.

As far as people "on this side" of the ramp are concerned, i.e. the group that we ourselves belonged to, we communicated with them daily during our stay at the camp, but with different intensity and with different focuses, that depended on the dominant function of the camp at the particular point. As far as the members of our group are concerned or volunteers that we established closer relationships with, our communication included longer conversations, and even discussions. Most other conversations, with other volunteers and employees, police officers and others, were short verbal exchanges of information and observations. They were, as is common in ethnographic research (cf. e.g. Hammersley and Atkinson 1996: 126-127), fleeting and related to concrete "everyday" situations in the field, encompassing various levels of life related to working at the camp, from the intimate and subjective to the material, and sometimes, although infrequently, relating to topics outside the camp. For example, after a short conversation with a police officer which revolved around the working conditions in the field, this is what we entered in our notes: "In Vinkovci, there are 25 of them to a room, 4 water boilers, 100 of them, 80 I boiler, he is showering in cold water." 
Sometimes during shorter fleeting conversations with volunteers and employees, we would touch upon controversial subjects about which, we presumed, our interlocutors knew more than we did. We would venture into these conversations with caution, limiting ourselves only to the surface of what was quietly talked about: why certain persons were boarded into railway cars after boarding had been finished and under police escort, whether there were people in the third sector, since when, how many of them, whether there were any children there, who was allowed to go there, etc. Similarly to the situation where we "covertly" recorded the shrieks of the young man who was being forcefully moved from one sector to another when we refrained from talking to other volunteers, in an effort to avoid covertly documenting their comments (cf. e.g. Lugosi 2008: 133), in this case we attempted not to mislead our interlocutors and to make them become informants unconsciously disloyal to their institutions or principles. From today's point of view, we see that - by working according to the ethnographic imperatives not to mislead, endanger or expose the other, and especially one's interlocutor through one's research (cf. e.g. Hammersley and Atkinson 264-273; Potkonjak 2014: 56) - we had, in a way, superimposed professional ethics to the ethics of solidarity with those whose lives were literally threatened and who were disempowered.

Volunteers and employees, moreover, were frequently uninformed about, or not interested in, broaching controversial or hidden subjects. Because of the automatized humanitarian support that created an environment of professionalism, as well as lack of interest for what went on beyond one's present task (cf. Harrell-Bond 2002), during the transit phase of the camp, the majority of employees and volunteers withdrew from their "workplace" after the train left the camp. After the closure of the corridor and the discontinuation of transit, however, because of the very fact that there were no tasks for most of them, it was generally more difficult to ignore the fact that there were hundreds of detained people in the camp that one had no access to. But even then, for some organizations, employees and volunteers, "professionalism" remained the key imperative in camp activities. This is, for example, evident from a comment given at the end of a meeting of non-governmental and other organizations with camp management, when the problem of detention in the camp was explicitly addressed for the first time. This is what our fieldnotes say:

For instance, at the end of the meeting, the representative of Samaritan Purse made a motion from the floor to leave out similar discussions (about the freedom of movement etc.) from common meetings, because they were not of interest to many, as they were there to discuss some specific operational issues. He said that people who were not interested had been biting their nails for the past twenty minutes. Several people nodded their heads in support [...].

Because of the way in which the camp functioned and how work was organized in it, because of organization hierarchy, and because, as was mentioned, we did not want to obtain information at the expense of exposing others, we primarily had to rely on our own observations in the camp, that took on full meaning only in retrospect. For instance, when the first reports about the detainment of refugees in the Slavonski Brod camp were pub- 
lished in late January and in February 2016 (Banich et al. 2016a; Moving Europe 2016), the lights that we had seen in January in the supposedly empty sectors of the camp and vans that took people and groups of people towards these sectors, rather than unclear fragments, now became signs of growing restrictions along the corridor, and the first clear signal of its soon-to-be final closure.

Our fieldwork observations, moreover, were nearly simultaneously complemented by the mentioned direct and indirect exchanges with volunteers of the organization that we volunteered for. As volunteers in the field, we were part of various online communication platforms, including group communication through mobile applications that we used to exchange largely operational information during our stay in the field. These chiefly very brief communication exchanges, which group coordinators used, among other things, as notes to write up daily reports from the field, became relevant research material only later, primarily as a source of chronology for the events and our being in the field. We transferred only few of them into our fieldnotes, notably those that related to a key event or incident, like the following one which came about before our research stay at the camp, in November 2015: "a police officer hit an elderly man, there was a report on whatsapp."

Moreover, parallel to our stays at the camp, we kept in touch with volunteers and activists outside the camp, some of whom we knew personally, and others only through various social network groups. We placed particular emphasis on communication through social networks, email and mobile phone apps in the final, detention phase of the camp. This communication, in addition to exchanges with volunteers and activists, included mediated exchanges with persons detained in the camp. We were in contact with them during this period even when we were not physically present in the camp, which is common in contemporary research as a way to keep in touch after the researcher leaves the field (cf. e.g. Moran 2016: 71). This type of communication, which is also common in contemporary ethnographic research (cf. Jackson 2016: 43-44), was one of the components of our study. On particular occasions, it had clear participatory elements, as was the case, for instance, when the refugees were being transferred into the center for asylum seekers in Zagreb and the detention in Ježevo (Incijativa Dobrodošli 2016). In an environment replete with contradictory information, the messages that one of us was exchanging with persons detained in the camp who faced the uncertainty of being moved, were directed at transmitting information (however partial), which were difficult to come by in the camp itself.

During this detention phase of the camp, one of us joined an online group established for the exchange of information about the isolation and detention of people in the Slavonski Brod camp. The group included, among others, people who had never been to the Slavonski Brod camp, but who had relevant information and knowledge about other camps, legislature etc. at their disposal, and people who were in contact with camp detainees or recent detainees. Among the numerous messages exchanged in the group, those which were primarily informative and operational prevailed, and they were of value 
in understanding the conditions of camp detention. Those notes that were written and sent directly from the camp, for instance when the closed sectors were opened to the volunteers, were often similar to fieldnotes and jottings that ethnographers write directly in the field, generally in preparation for longer later notes (cf. e.g. Emerson et al. 1995: 30-35). A small part of those was more similar to ethnographic descriptions and contained detailed observations about a single or several events in the camp, e.g. about collective registration of detained refugees after the closure of the corridor, which was a way to attempt to formalize their detention, about the meeting with the camp manager, or about the transfer of "single men" from one sector to another.

Some internal working reports emailed in the first days after the sectors had been open to volunteers, which aimed at providing as much detail as possible to the organization that the volunteers worked for, also had the characteristics of ethnographic description. These reports, in addition to playing a significant role in informing the following group of volunteers, were also important as a tool of harmonizing opinions within the organization, in relation to its immediate activities in the field, and long-term advocacy. These detailed day or half-day reports, which seemed like a way to counterweigh the previous information vacuum concerning the closed sectors, were saturated with observations about people, their destinies and events in the closed sectors, as well as reflections on one's own position as a person reporting about them.

We archived these field reports, and some of the exchanges in the online groups, both those with volunteers and activists and those with camp detainees, together with our notes, recognizing the research potential for understanding the camp, not only through our own notes and reports, but also through those written by others. Messages and reports that we received from the volunteers in the camp, and that, irrespective of whether we were at the camp at the time or not, sometimes related to events that we ourselves had not seen, deepened our knowledge about the camp, and included the perspectives and experiences of others into them. With their help, and with the help of messages that we exchanged with persons detained in the camp, we were able to retain a connection with the field after we had physically left it, continuing, in a way "remote" fieldwork (Moran 2016: 66). In other words, they enabled us, even when we were not in the camp, to follow the everyday life of the camp and the key events in it, as well as, as had already been mentioned, to remotely and intensely take part in them, in a way.

All these texts are part of our fieldnote corpus, as currently seen in considerations of ethnographic notes (cf. Jackson 2016: 43-44). This puts into question the generalized definition of fieldnotes as texts that ethnographers write for themselves (Emerson et al. 1995: 44), which is a topic that, like so many other methodological topics touched upon in this paper, could be further extended (cf. e.g. Nardi 2016). We would like to note here that the texts written by others still had a somewhat different status for us as researchers. In addition to those differences related primarily to their potential publishing, they had a special status for us with regard to how we felt about their potential loss. Concern over the 
possibility of losing one's own notes, which the ethnographer uses to draw up the final text, and which is, therefore, latently or explicitly present in all ethnographic research in general (cf. e.g. Sanjek 1991: 35-38), took on additional dimensions in the context of our research in the camp. Our concern was deepened by our fear that the loss of fieldnotes would result in exposing the people mentioned in them, as well as the people who wrote some of them, and the fear about the potential and very tangible existential repercussions for all those involved, which was related to the camp environment and the wider securitarian and repressive framework of migration management.

\section{REDUCTIONISM AND PLURALISM}

In sum, our research in the Slavonski Brod camp was characterized by both methodological reductionism and methodological pluralism. Certain ethnographic methods, as we have tried to show, boiled down to their bare contours, however, upon taking a step away or combined with other ethnographic methods, they opened and created multiple doorways into the research field. Moreover, our research had many characteristics of investigative work, evident, for instance, in our techniques of scanning inaccessible spaces, external observation, and the described networking with people who shared our interest in reconstructing events in the camp. In an environment where so much was hidden or inaccessible for various reasons, we continually had to discover the basic stratum of the world that we were studying, which the researchers in other contexts generally reach immediately, and without major difficulty. This is why we could not focus our research attention to the interpretations, personal views and perspectives of other, i.e. on the level that ethnography is primarily concerned with, and we had to base our conclusions on partial, sparse and often mediated insights, which, in some circumstances, were the only ones possible in the camp environment, as we have shown above. Still, continued fieldwork based on a diversified ethnographic methodology, and the openness to problematize and question, resulted in a specific research perspective, which, we believe, despite its limitations, opens places of difference in relation to the dominant views of what had been very broadly reduced to the common denominator of refugee crisis in Croatia.

\section{REFERENCES AND SOURCES}

Agier, Michel. 2015. Managing the Undesirables. Refugee Camps and Humanitarian Government. Cambridge, Malden, MA: Polity Press.

Allu Davies, Charlotte. 2001. Reflexive Ethnography. A Guide to Researching Selves and Others. London, New York: Routledge.

Atkinson, Paul. 2015. For Ethnography. Los Angeles etc.: Sage Publications.

Banich, Selma, Lukas Gerbig and Adrienne Homberger. 2016a. Report on Systemic Police Violence and Push-Backs against Non-SIA People Conducted by Croatian Authorities. (Moving Europe Project,28 
January 2016). Available at: http://moving-europe.org/wp-content/uploads/2016/01/28.01.2016_ Report-Police-Violence-and-Push-Backs.pdf.

Banich, Selma, Sunčica Brnardić, Marijana Hameršak, Sara Kekuš, Iva Marčetić, Mojca Piškor and Magda Sindičić. 2016b. Report on Systemic Human Rights Violations by the Croatian Authorities in the Closed Parts of the Winter Reception and Transit Centre in Slavonski Brod (16 January 2016). Available at: http://cms.hr/system/article_document/doc/261/Report_on_Systemic_Human_Rights_ Violations_in_the_Winter_Reception_and_Transit_Centre_in_Slavonski_Brod.pdf.

Belloni, Roberto. 2007. "The Trouble with Humanitarianism”. Review of International Studies 33: 451474. [https://doi.org/10.1017/S0260210507007607]

Bošković-Stulli, Maja. 1998. "Institutska davna mitska prošlost". Narodna umjetnost 35/2: 269-275.

Čapo, Jasna. 2015a. "The Security-scape and the (In)Visibility of Refugees. Managing Refugee Flow through Croatia”. Migracijske i etničke teme 31/3: 387-406.

Čapo, Jasna. 2015b. “Od Opatovca do Strasbourga. Razna lica izbjegličke "krize”. Zbornik Trećeg programa Hrvatskog radija 87: 5-17.

Clifford, James. 1983. "On Ethnographic Authority". Representations 1/2: 118-146. [https://doi. org/10.2307/2928386]

Cobarrubias, Sebastian, Maribel Casas-Cortes, Glenda Garelli, Charles Heller, Lorenzo Pezzani, John Pickles and Martina Tazzioli. 2015. "Externalization". Journal of Cultural Studies (New Keywords. Migration and Border, ed. Nicholas De Genova, Sandro Mezzadra and John Pickles) 29/1: $19-22$.

Hrvatski Crveni križ. 2016. Godišnje izvješće o radu u 2015. godini. Available at: http://www.hck.hr/ upload_data/txt_editor/info/GODISNJE_IZVJESCE_2015.pdf.

De Genova, Nicholas, Elena Fontanari, Fiorenza Picozza, Laia Soto Bermant, Aila Spathoupoulou, Maurice Stierl, Martina Tazzioli, Huub van Baar and Can Yildiz. 2016. "'Migrant Crisis'/'Refugee Crisis"'. Near Futures On line. Europe at Crossroads. Managed Inhospitality (Europe/Crisis. New Keywords of "the Crisis" in and of "Europe", ed. Nicholas De Genova and Martina Tazzioli) 1: 15-21. Available at: http:// nearfuturesonline.org/wp-content/uploads/2016/01/New-Keywords-Collective_11.pdf.

Documenta - centar za suočavanje s prošlošću. 2015. Humanost u trenucima izbjegličke krize. Izvještaj o potrebama i radu s izbjeglicama. Available at: http://www.documenta.hr/assets/files/objave/2015-06/Humanost-u-trenucima-izbjeglicke-krize--Izvjestaj.pdf.

Donnan, Hastings and Thomas M. Wilson. 2010. "Ethnography, Security and the 'Frontier Effect' in Borderlands". In Borderlands. Ethnographic Approaches to Security, Power and Identity. Hastings Donnan and Thomas M. Wilson, eds. Lanham, Maryland: University Press of America, 1-20.

Đurin, Sanja. 2011. “Lepoglavski panoptikon. Prostor, moć, identitet”. In Mjesto, nemjesto. Interdisciplinarna promišljanja prostora i kulture. Jasna Čapo and Valentina Gulin Zrnić, eds. Zagreb, Ljubljana: Institut za etnologiju i folkloristiku, Inštitut za antropološke in prostorne študije, ZRC, SAZU, 269-285.

Düvell, Franck, Anna Triandafyllidou and Bastian Vollmer. 2009. "Ethical Issues in Irregular Migration Research in Europe". Population, Space and Place 16/3: 227-239. [https://doi.org/10.1002/psp.590]

Ehn, Billy, Orvar Löfgren and Richard Wilk. 2016. Exploring Everyday Life. Strategies for Ethnography and Cultural Analysis. Lanham, Maryland, London: Rowman \& Littlefield.

Emerson, Robert M., Rachel I. Fretz and Linda L. Shaw. 1995. Writing Ethnographic Fieldnotes. Chicago, London: The University of Chicago Press. [https://doi.org/10.7208/chicago/9780226206851.001.0001]

Etički kodeks Hrvatskog etnološkog društva. 2013. Available at: http://www.hrvatskoetnoloskodrustvo. hr/o-nam/eticki-kodeks-hed-a/.

Gregurović, Margareta, Simona Kuti and Drago Župarić-Iljić. 2016. "Attitudes towards Immigrant Workers and Asylum Seekers in Eastern Croatia. Dimensions, Determinants and Differences". Migracijske i etničke teme 32/1: 91-122. 
Hammersley, Martyn and Paul Atkinson. 1996. Ethnography. Principles in Practice. London: Routledge.

Harrell-Bond, Barbara and Eftihia Voutira. 2007. "In Search of 'Invisible' Actors. Barriers to Access in Refugee Research". Journal of Refugee Studies 20/2: 281-298. [https://doi.org/10.1093/jrs/fem015]

Harrell-Bond, Barbara. 2002. "Can Humanitarian Work with Refugees be Humane?". Human Rights Quarterly 24: 51-85. [https://doi.org/10.1353/hrq.2002.0011]

Hopkins, Mary Carol. 1993. "Is Anonymity Possible? Writing about Refugees in the United States". In When they Read What We Write. The Politics of Ethnography. Caroline B. Brettell, ed. Westport: Bergin \& Garvey, 121-129.

Huysmans, Jef. 2006. The Politics of Insecurity. Fear, Migration and Asylum in EU. London, New York: Routledge.

Inicijativa Dobrodošli. 2015. Terenski vodič za volontere/ke i koordinatore/ice volontera (e-brochure).

Inicijativa Dobrodošli. 2016. Zidne novine Inicijative Dobrodošli. Kriminalizacija i detencija izbjeglica preseljenih iz kampa u Slavonskom Brodu (9 May 2016). Available at: http://www.cms.hr/hr/azili-integracijske-politike/objavljene-zidne-novine-kriminalizacija-i-detencija-izbjeglica-inicijative-dobrodosli.

Jackson, Jean E. 2016. "Changes in Fieldnotes Practice over Past Thirty Years of U. S. Anthropologists". In eFieldnotes. The Makings of Anthropology in the Digital World. Roger Sanjek and Susan W. Tratner, eds. Philadelphia: University of Pennsylvania Press, 42-62.

Jacobsen, Karen and Loren B. Landau. 2003. "The Dual Imperative in Refugee Research. Some Methodological and Ethical Considerations in Social Science Research on Forced Migration". Disasters 27/3: 185-206. [https://doi.org/10.1111/1467-7717.00228]

Jambrešić Kirin, Renata and Tea Škokić. 2016. “Shopping centar nenormalne normalnosti”. Paper presented at the conference Kamp, kolodvor, granica. Mikrostudije izbjeglištva u suvremenom hrvatskom kontekstu (CMS; CEDIM and IEF, Zagreb, 14-15 June 2016).

Kasparek, Bernd. 2016. "Routes, Corridors, and Spaces of Exception. Governing Migration and Europe". Near Futures - On line- Europe at a Crossroads. Managed Inhospitality 1. Available at: http://nearfuturesonline.org/wp-content/uploads/2016/01/Kasparek_Final_PDF.pdf.

Kość-Ryżko, Katarzyna. 2012-2013. “The Refugee Centre as Field of Research”. Ethnologia Polona 3334: 229-241.

Larsen, Maren, Elma Demir and Maja Horvat. 2016. Humanitarian Responses by Local Actors. Lessons Learned from Managing the Transit of Migrants and Refugees through Croatia. IIED Working Paper. London: IIED. Available at: http://pubs.iied.org/pdfs/10795IIED.pdf.

Lugosi, Peter. 2008. “Covert Research”. In The Sage Encyclopedia of Qualitative Research Methods, 2. Lisa M. Given, ed. Thousand Oaks, CA: Sage, 133-136.

Martinović Džamonja, Dragica, Ellen Nygern and Marina Škrabalo, with the cooperation of Ana Dumitrache. 2016. EESC Fact-Finding Missions on the Situation of Refugees, as Seen by Civil Society and Organisations. Mission Report - Croatia, 12 and 13 January 2016. European Economic and Social Committee. Available at: http://www.eesc.europa.eu/resources/docs/croatia_migration-mission-report_en.pdf.

Moran, Mary H. 2016. “The Digital Divide Revisited. Local and Global Manifestations". In eFieldnotes. The Makings of Anthropology in the Digital World. Roger Sanjek and Susan W. Tratner, eds. Philadelphia: University of Pennsylvania Press, 65-77. [https://doi.org/10.9783/9780812292213-005]

Mouzourakis, Minos and Amanda Taylor. 2016. Wrong Counts and Closing Doors. The Reception of Refugees and Asylum Seekers in Europe (Asylum Information Database). European Council on Refugees and Exiles. Available at: http://www.asylumineurope.org/sites/default/files/shadow-reports/ aida_wrong_counts_and_closing_doors.pdf. 
Moving Europe. 2016. Report on Human Rights Violations and Push-Backs Against People Travelling Towards Germany Conducted by Austrian, Slovenian and Croatian Authorities (26 February 2016). Available at: http://moving-europe.org/report-on-human-rights-violations-and-push-backs-against-people-travelling-towards-germany-conducted-by-austrian-slovenian-and-croatian-authorities/.

Nardi, Bonnie A. 2016. "When Fieldnotes Seem to Write Themselves. Ethnography Online". In eFieldnotes. The Makings of Anthropology in the Digital World. Roger Sanjek and Susan W. Tratner, eds. Philadelphia: University of Pennsylvania Press, 192-209.

Ured pučke pravobraniteljice. 2016. Izvješće pučke pravobraniteljice za 2015. godinu (31 March 2016). (The report has not been accepted). No longer accessible online as of 7 October 2016.

Ottenberg, Simon. 1991. "Thirty Years of Fieldnotes. Changing Relationships to the Text". In Fieldnotes The Makings of Anthropology. Roger Sanjek, ed. Ithaca, London: Cornell University Press, 139-160.

Petrović, Duško and Romana Pozniak. 2014. "Tražitelji azila kao prijetnja". Studia ethnologica Croatica 26: $47-72$.

Petrović, Duško. 2016. Izbjeglištvo u suvremenom svijetu. Od političkoteorijskih utemeljenja do biopolitičkih ishoda. Zagreb: Naklada Ljevak.

Potkonjak, Sanja. 2014. Teren za etnologe početnike. Zagreb: HED.

Puljizević, Lada. 2015. “Izgradnja zimskog kampa za izbjeglice”. Hrvatski vojnik 485. Available at: https:// hrvatski-vojnik.hr/godina-2015-menu/item/1197-izgradnja-zimskog-kampa-za-izbjeglice.html.

Sanjek, Roger. 1991. "Fire, Loss, and the Sorcerer's Apprentice”. In Fieldnotes. The Makings of Anthropology. Roger Sanjek, ed. Ithaca, London: Cornell University Press, 34-44.

Scheel, Stephan, Glenda Garelli and Martina Tazzoli. 2015. "Politics of Protection”. Journal of Cultural Studies (New Keywords. Migration and Border, ed. Nicholas De Genova, Sandro Mezzadra and John Pickles) 29/1: 16-19.

Šelo Šabić, Senada and Sonja Borić. 2016. At the Gate of Europe. A Report on Refugees on the Western Balkan Route. Fridrich Erbert Stifung. Available at: http://www.irmo.hr/wp-content/ uploads/2016/05/At-the-Gate-of-Europe_WEB.pdf.

Sherman Heyl, Barbara. 2007. "Ethnographic Interviewing”. In Handbook of Ethnography. Paul Atkinson, Amanda Coffey, Sara Delamont, John Lofland and Lynn Lofland, eds. Los Angeles etc.: Sage Publications, 369-383.

Sigurnosno-obavještajna agencija. 2016. Javno izvješće. Available at: https://www.soa.hr/UserFiles/File/ pdf/Javno-izvjesce-2016.pdf.

Smith, Valerie. 2009. "Ethical and Effective Ethnographic Research Methods. A Case Study with Afghan Refugees in California". Journal of Empirical Research on Human Research Ethics 4/3: 59-72. [https://doi.org/10.1525/jer.2009.4.3.59]

Spradley, James P. 1980. Participant Observation. Fort Worth, Philadelphia: Harcourt Brace Jovanovich College Publishers.

Stierl, Maurice, Charles Heller and Nicholas De Genova. 2016. "Numbers (Or, the Spectacle of Statistics in the Production of 'Crisis')". Near Futures - On line. Europe at Crossorads. Managed Inhospitality (Europe/Crisis. New Keywords of "the Crisis" in and of "Europe". Nicholas De Genova and Martina Tazzioli, eds.) 1: 21-25. Available at: http://nearfuturesonline.org/europecrisis-new-keywords-of-crisis-in-and-of-europe-part-4/.

Vlada Republike Hrvatske. 2015. Odluka o osnivanju stožera za koordinaciju aktivnosti povodom dolaska migranata u Republiku Hrvatsku. Draft version available at: https://vlada.gov.hr/UserDocslmages/Sjednice/2015/253\%20sjednica\%20Vlade/253\%20-\%2013.pdf. 
Wacquant, Loïc. 2002. "The Curious Eclipse of Prison Ethnography in the Age of Mass Incarceration". Ethnography 3/4: 371-397. [https://doi.org/10.1177/1466138102003004012]

Walters, William. 2004. "Secure Borders, Safe Haven, Domopolitics". Citizenship Studies 8/3: 237-260. [https://doi.org/10.1080/1362102042000256989]

Weiss, Thomas G. 2013. Humanitarian Business. Cambridge: Polity Press.

Wilsher, Daniel. 2012. Imigration Detention. Law, History, Politics. Cambridge: Cambridge University Press.

Župarić-Iljić, Drago and Margareta Gregurović. 2013. "Stavovi studenata prema tražiteljima azila u Republici Hrvatskoj”. Društvena istraživanja 22/1: 41-62.

Župarić-lljić, Drago. 2013. "Percepcija tražitelja azila u javnosti i medijski prikazi problematike azila u Hrvatskoj". In Prvih deset godina razvoja sustava azila u Hrvatskoj (s osvrtom na sustave azila u regiji). Drago Župarić-lljić, ed. Zagreb: Institut za migracije i narodnosti, Centar za mirovne studije, Kuća ljudskih prava, 201-220.

\section{ZIMSKI PRIHVATNO-TRANZITNI CENTAR REPUBLIKE HRVATSKE: ETNOGRAFSKO RAZUMIJEVANJE SLAVONSKOBRODSKOG KAMPA ZA IZBJEGLICE}

Od siječnja do travnja 2016. godine u više smo navrata boravile u Zimskom prihvatnotranzitnom centru, odnosno slavonskobrodskom kampu za izbjeglice koji je u tom trenutku bio jedino mjesto u Hrvatskoj predviđeno za zaustavljanje izbjeglica iz ratom pogođenih, i na druge načine depriviranih zemalja svijeta na putu prema zapadnoj Europi. U radu se bavimo metodološkim pitanjima, istraživačkim metodama i postupcima (u rasponu od ulaska na teren te pitanja istraživačkih i sudioničkih uloga, preko promatranja i bilježenja do sudjelovanja, intervjua i razgovora) koje smo iskušavale i na kojima smo ustrajavale tijekom našeg boravka u kampu, a koje vidimo kao važne za razumijevanje samog kampa i onoga što se u njemu događalo. Fokusiramo se na brojna lica metodološkog redukcionizma i metodološkog pluralizma našeg istraživanja u kampu. Pojedine etnografske metode u našem su se istraživanju često svodile na svoje konture da bi u odmaku ili nadogradnji s drugim metodama otvarale i oblikovale mnogostruke ulaze $u$ istraživačko polje, poprimajući pritom i obilježja istražiteljskog rada.

Ključne riječi: metodologija, etnografija, izbjeglištvo, izbjeglički kamp, promatranje sa sudjelovanjem, bilježenje, inervju i razgovor 